九州大学学術情報リポジトリ

Kyushu University Institutional Repository

\title{
Ribosomes and Messenger RNA in the Debrained Pupae of Bombyx mori
}

Shimizu, Hideki

Laboratory of Sericultural Chemistry, Department of Agriculture, Kyushu University

Yamao, Masami

Laboratory of Sericultural Chemistry, Department of Agriculture, Kyushu University

Koga, Katsumi

Laboratory of Sericultural Chemistry, Department of Agriculture, Kyushu University

Hayashi, Katsuya

Laboratory of Sericultural Chemistry, Department of Agriculture, Kyushu University

https://doi.org/10.5109/23484

出版情報：九州大学大学院農学研究院紀要. 21 (1)，pp. 25-31，1977-02. Kyushu University バージョン：

権利関係 : 


\title{
Ribosomes and Messenger RNA in the Debrained Pupae of Bombyx mori
}

\author{
Hideki Shimizu*, Masami Yamao $\dagger$, Katsumi Koga \\ and Katsuya $\mathrm{H}$ ayashi
}

\author{
Laboratory of Sericultural Chemistry, Department of Agriculture, \\ Kyushu University 46-02, Fukuoka 812
}

(Received August 31, 1976)

\begin{abstract}
The content of ribosomes and the activity of endogenous mRNA increased during adult development in the female pupae of Bombyx mori, but debrained pupae of a strain N122 $\times$ C115 did not show such increases. The debrained pupae synthesized ribosomal RNA after injection of ecdysterone. Most of the synthesis was found in the ovaries. The ovaries also exhibited increased activity of endogenous mRNA after injection of the hormone.
\end{abstract}

\section{INTRODUCTION}

Kobayashi (1955) found that removal of the brain from Bombyx mori arrested adult development, and resulted in a pupal diapause. Since Bombyx can be raised copiously, diapausing pupae of this strain may serve as convenient materials not only for endocrinological study (e.g. Yamazaki and Kobayashi, 1969) but also for elucidation of metabolic control and developmental processes. It has been demonstrated that in the diapause pupae the sugar content is low and the switchover of carbohydrate metabolism from glycogen synthesis to trehalose synthesis is retarded (Kobayashi and Kimura, 1967). However, knowledge of protein synthesis in relation to the diapause is scarce. The present study deals with the content and synthesis of ribosomes and the activity of endogenous messenger RNA (mRNA) in the debrained pupae of Bombyx mori.

\section{MATERIALS AND METHODS}

\section{Animals}

Female pupae of a hybrid between two races N122 and C115 were used since it has been shown that dormant pupae can be obtained only when this hybrid is used (Kobayashi, 1957; Kobayashi and Yamashita, 1958). Shortly after larvalpupal ecdysis (within $2 \mathrm{hr}$ ) the brains were extirpated as described previously (Ishizaki, 1972; Kobayashi, 1955) and then kept at $25^{\circ} \mathrm{C}$. Some of the debrained pupae were soon subjected to experiments. The rest were kept for 30 days

\footnotetext{
* Present address: Asahi Chemical Industry Co. Ltd., Foods and Fine Chemicals Plant, Nobeoka.

+ Present address: The Tokushima Horticultural Experiment Station, Katsuura. Tokushima.
} 
and individuals which showed no sign of adult development were used as "Dauer pupae" (Kobayashi, 1955). Before use they were injected with $10 \mu \mathrm{g}$ per head of ecdysterone (Rhoto Pharmaceutical Co. Ltd.) in $10 \mu \mathrm{l}$ of $10 \%$ ethanol.

\section{Preparation of ribosomes}

Ribosomes were prepared from the whole body of the pupae according to Sridhara and Levenbook (1974) with some modifications (Yamao and Koga, 1975). The $A_{260}$ values of the ribosomes were determined and recalculated to represent $\mathrm{mg}$ per individual assuming that $1 \mathrm{mg}$ of ribosomes possess $10 \mathrm{~A},$, .. Validity of the procedure is discussed in detail in a separate paper (Shimizu et al., 1977). Isolated ribosomes were also assayed for amino acid-incorporating activity as described below.

\section{Preparation of cell-free extracts (lysates)}

The ovaries were homogenized and gel-filtrated as described previously (Tamaoki et al., 1974). The void fraction (lysate) was assayed for amino acidincorporating activity.

\section{Assay of amino acid-incorporating activities}

The isolated ribosomes and the lysates were assayed for incorporation of ${ }^{3} \mathrm{H}$-leucine plus 19 other amino acids due to endogenous mRNA and incorporation of ${ }^{3} \mathrm{H}$-phenylalanine due to added poly(U). Details were described in previous papers (Koga and Tamaoki, 1974; Yamao and Koga, 1975).

\section{RNA synthesis in Dauer pupae after hormone-administration}

Dauer pupae (30 days after larval-pupal ecdysis, see above) were injected with ecdysterone as described above and kept at $27^{\circ} \mathrm{C}$ for up to 7 or 11 days as indicated. At intervals 2 pupae were taken and each was injected with $2 \mu \mathrm{Ci}$ of $\left[5-{ }^{3} \mathrm{H}\right]$ uridine $(5 \mathrm{Ci} / \mathrm{mmol})$ or a mixture of $0.25 \mu \mathrm{Ci}$ of $\left[2{ }^{14} \mathrm{C}\right]$ uridine $(0.05 \mathrm{Ci} /$ mmol) plus $5 \mu \mathrm{Ci}$ of ${ }_{\mathrm{L}}-\left[\right.$ methyl $\left.{ }^{3} \mathrm{H}\right]$ methionine $(5 \mathrm{Ci} / \mathrm{mmol})$ in $10 \%$ ethanol $(10 \mu \mathrm{l})$. The injected pupae were kept for another $24 \mathrm{hr}$ and then sacrificed. Total nucleic acids were extracted from the whole body or from each tissue as described previously (Okabe et al., 1975) and analyzed by a methylated albumin column according to Mandell and Hershey (1960) or by polyacrylamide-gel according to Loening (1967). Effluents from the column were determined for A,,, and counted in Triton-toluene (1: 2) by a scintillation counter. The gel was scanned as described previously (Okabe et al., 1975), sliced, dissolved and counted according to Koga and Tamaoki (1974).

\section{Effect of actinomycin $\mathbf{S}_{2}$ (AMS) on the response of the ovaries to ecdysterone}

Dauer pupae were injected with ecdysterone as above and kept for 7 days at $27^{\circ} \mathrm{C}$. During the period the pupae received AMS (Daiichi Pure Chemicals Co. Ltd.) in $10 \mu \mathrm{l}$ of $10 \%$ ethanol. In order to avoid possible catabolism of AMS, its administration was made every 2 days, i.e. up to 4 times. The dose of the drug at each administration is indicated in Fig. 5. Lysates of the ovaries were prepared and their activities to incorporate ${ }^{3} \mathrm{H}$-leucine due to endogenous 
mRNA and to incorporate ${ }^{3} \mathrm{H}$-phenylalanine due to added poly(U) were assayed as described above. The sample of AMS-minus (dose zero) exhibited significant incorporation upon both types of incubation. The results (Fig. 5) are expressed in terms of relative activity.

\section{RESULTS}

\section{The content of ribosomes in the debrained pupae}

Changes in the ribosome content were studied for up to 9 or 10 days after larval-pupal ecdysis. The results are depicted in Fig. 1. The brainless pupae exhibited a specific pattern without showing the maximum that appeared at day 7 in the control pupae (sham-operated or not). The variation in the normal pupae is discussed in a separate paper (Shimizu et al., 1977).

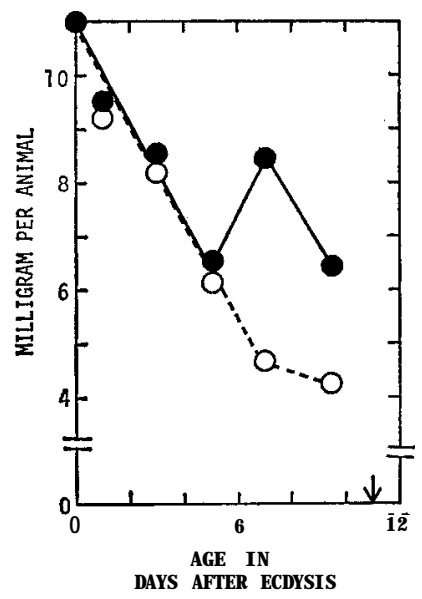

Fig. 1. Changes in content of ribosomes in the debrained pupae (open circles) and in the normal pupae (solid circles). Zero day is the day of larval-pupal ecdysis. The normal pupae attained adult emergence on the 11th day (arrow.)

\section{Activity of endogenous mRNA in the debrained pupae}

The activity of natural mRNA which was attached to isolated ribosomes were assayed by the amino acid-incorporating system. As shown in Fig. 2, the control animals (sham-operated or not) attained a drastic increase in the activity 9 to 10 days after larval-pupal ecdysis (cf. also Yamao and Koga, 1975), while the debrained pupae did not show such an increase.

\section{RNA synthesis in Dauer pupae after injection of ecdysterone}

Dauer pupae were injected with ecdysterone and RNA synthesis was studied as described in Methods. Figure 3 shows the results of methylated albumin column chromatography with the labeled nucleic acids from the whole bodies. The last peak in each chromatograph may represent ribosomal $(28 \mathrm{~S}+18 \mathrm{~S})$ 


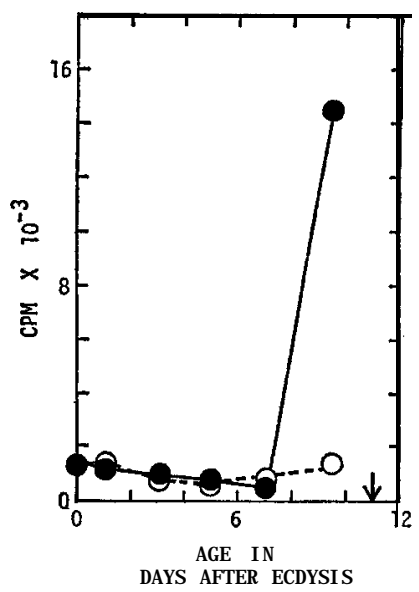

Fig. 2. Changes in activity of endogenous mRNA in the debrained pupae (open circles) and in the normal pupae (solid circles). Kibosomes were prepared and assayed for ${ }^{3} \mathrm{H}-$-leucine incorporation due to endogenous mRNA as described in Methods. For the other comments see the legend to Fig. 1.

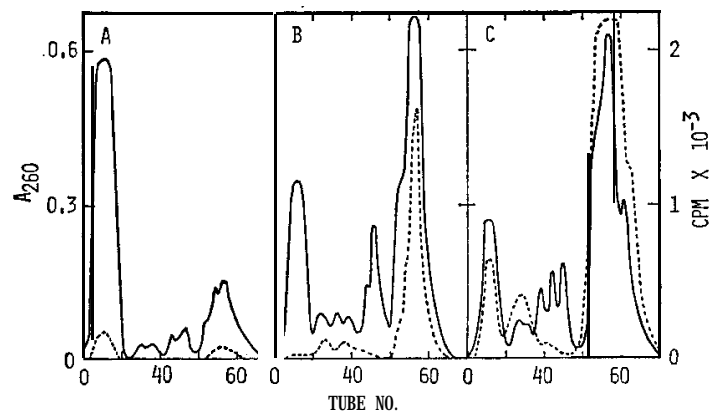

Fig. 3. Incorporation of ${ }^{3} \mathrm{H}$-uridine into nucleic acids of Dauer pupae after injection of ecdysterone. Dauer pupae were injected with ${ }^{3} \mathrm{H}$-uridine after receiving $10 \%$ ethanol only (A), and 1 day (B) and 7 days (C) after receiving ecdysterone. Total nucleic acids from the whole bodies were analyzed by a methylated albumin column. Details are described in Methods. Solid line represents $A_{260}$ and broken line represents the counts.

RNA (rRNA). Figure 4 shows the counts of rRNA as analyzed by polyacrylamide-gel electrophoresis of nucleic acids from each tissue. One day after ecdysterone-treatment the incorporation of the RNA-precursors into rRNA had already been significantly accelerated, and after 7 days it reached a maximum level. As seen in Fig. 4, the ovaries occupied most of the increasing activities, while other tissues (totalized in Fig. 4) had a tendency to decrease in incorporation after the hormone-treatment. The apparent changes of incorporation in the ovaries may not be the reflection of some change in precursor pools because two different precursors, uridine and the methyl group, took similar patterns (Fig. 4). It may be inferred that the rRNA synthesis exhibited by the ovaries 
in response to ecdysterone-treatment is rapid in the sense that it showed no threshold as far as studied under the present experimental conditions (Fig. 4).

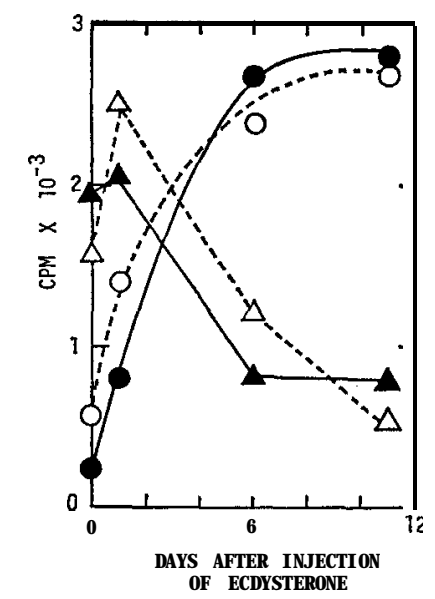

Fig. 4. Incorporation of RNA-precursors into rRNA in the organs of Dauer pupae after injection of ecdysterone. Dauer pupae were injected with a mixture of ${ }^{14} \mathrm{C}-$ uridine plus [methyl ${ }^{3} \mathrm{H}$ ] methionine at indicated days (along abscissa) after administration of ecdysterone. Nucleic acids were analyzed by polyacrylamide-gel electrophoresis as described in Methods and the counts per $\mathbf{A}_{260}$ of rRNA ( $28 \mathrm{~S}+18 \mathrm{~S}$ ) from the ovaries (circles) and the total of other organs (triangles) are depicted. Solid symbols represent the counts of ${ }^{14} \mathrm{C}$ and open symbols represent those of ${ }^{3} \mathrm{H}$.

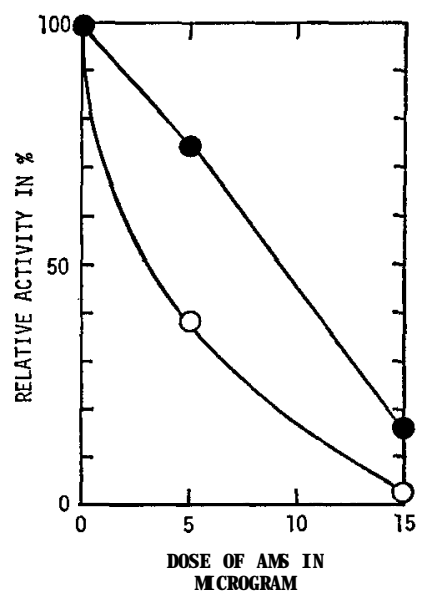

Fig. 5. Effect of AMS on the response of the ovaries to ecdysterone. Dauer pupae which received ecdysterone were injected with AMS at the indicated doses (along abscissa) and the lysates from the ovaries were assayed for the activity of endogenous mRNA (solid circles) and of poly(U)dependent ribosomal activity (open circles). For details see Methods. 


\section{Effect of AMS on the response of the ovaries to ecdysterone}

in order to test the possibility that the ovaries synthesize mRNA in response to ecdysterone, the effect of AMS on the appearance of the activity of endogenous mRNA in the ovaries was investigated. Seven days after injection of the hormone the ovaries from the animals which received no AMS showed a high level of ${ }^{3} \mathrm{H}$-leucine-incorporating activity $(4482 \mathrm{cpm})$. Moreover, these ovaries had a high level of ribosomal activity as assayed by poly(U)-dependent ${ }^{3} \mathrm{H}$-phenylalanine-incorporation $(5796 \mathrm{cpm})$. As seen in Fig. 5, both the incorporations were lower in the organs from the AMS-treated animals than those with the AMS-minus animals, suggesting that de novo synthesis of mRNA as well as ribosomes may occur in the ovaries and these were inhibited by AMS. The apparent inhibition for ribosomes seemed to be more significant than that for mRNA. This coincides with the generally accepted principle for the action of actinomycin. However, whether or not AMS affects the turnover-rate of mRNA and ribosomes is unknown at present.

\section{DISCUSSION}

There is evidence that the increase in both the ribosome content (Fig. 1) and the endogenous mRNA activity (Fig. 2) in the normal pupae are mainly contributed by the ovaries (Shimizu et al., 1977), while in the debrained pupae no such increases were observed, indicating that development of the ovaries was arrested by the extirpation of the brains. It is known that the ovaries in the normal pupae develop autonomously; fundamental steps for their growth do not depend upon endocrinological systems (Paul et al., 1972). However, the present study shows that the ovaries in Dauer pupae significantly respond to ecdysterone; rRNA synthesis was stimulated without showing a threshold after administration of the hormone as far as studied under the present conditions (Fig. 4). The hormone may also stimulates the synthesis of mRNA as suggested by the result of the AMS-experiment (Fig. 5). Irrespective of whether or not these types of stimulation may be effected in an indirect manner, the ovaries in Dauer pupae will serve as a convenient tool for study of mechanisms related to the control of protein synthesis which is under investigation in our laboratory.

\section{ACKNOWLEDGEMENTS}

The authors are greatly indebted to Dr. Masatoshi Kobayashi of the Sericultural Experiment Station (Tokyo) for suggesting the use of Dauer pupae in the study and for invaluable advice during the work. They also express sincere thanks to Mr. Masaki Nagashima and to Mr. Teruo Okajima of the Sericultural Experiment Station (Kyushu) for raising the silkworm and help to prepare the debrained pupae. Thanks are due to Dr. Shuntaro Ogawa of Rhoto Pharmaceutical Co. Ltd. for his kind supply of ecdysterone. A part of this work was supported by a grant from the Ministry of Education. 


\section{REFERENCES}

Ishizaki H. 1972 Arrest of adult development in debrained pupae of the silkworm, Bombyx mori. J. Insect Physiol., 18: 1621-1627

Kobayashi, M. 1955 Relationship between the brain hormone and the imaginal differentiation of the silkworm, Bombyx mori. J. Sericult. Sci. Jap., 24: 389-392

Kobayashi, M. 1957 Studies on the neurosecretion in the silkworm, Bombyx mori L. Bull. Sericult. Exp. Sta., 15: 181-273

Kobayashi, M. and S. Kimura 1967 Action of ecdysone on the conversion of W-glucose in dauer pupa of the silkworm, Bombyx mori. J. Insect Physiol., 13: 545-552

Kobayashi, M. and Y. Yamashita 1958 Seasonal differences in the rates of the appearance of 'Dauer-pupa' in the silkworm, Bombyx mori L. J. Sericult. Sci. Jap., 27: 93-98

Koga, K. and T. Tamaoki 1974 Developmental changes in the synthesis of a-fetoprotein and albumin in the mouse liver. Cell-free synthesis by membrane-bound polyribosomes. Biochemistry, $13: 3024-3028$

Loening, U. E. 1967 The fractionation of high-molecular-weight ribonucleic acid by polyacrylamide-gel electrophoresis. Biochem. J., 102: 251-257

Mandell, J. D. and A. D. Hershey 1960 A fractionating column for analysis of nucleic acids. Anal. Biochem., 1: 66-77

Okabe, K., R. Koyanagi and K. Koga 1975 RNA in the degenerating silk gland of Bombyx mori. J. Insect Physiol., 21: 1305-1309

Paul, M., M. R. Goldsmith, J. R. Hunsley and F. C. Kafatos 1972 Specific protein synthesis in cellular differentiation. Production of eggshell proteins by silkmoth follicular cells. J. Cell Biol., 55: 653-680

Shimizu, S., M. Yamao, 0. Nakamura, N. Hamada, K. Koga and K. Hayashi 1977 Developmental changes of ribosomes in content and amino acid incorporating activities in the female pupae of Bombyx mori. Agric. Biol. Chem., 41: 311-314

Sridhara, S. and L. Levenbook 1974 The contribution of the fatbody to RNA and ribosomal changes during development of the blowfly Calliphora erythrocephala (Meig.). Develop. Biol., 38: 64-72

Tamaoki T., K. Thomas and I. Schindler 1974 Cell-free studies of developmental changes in synthesis of $\alpha$-foetoprotein and albumin in the mouse liver. Nature, 249: 269-271

Yamao, M. and K. Koga 1975 Control of protein synthesis in the female pupa of Bombyx mori. Agric. Biol. Chem., 39: 1519-1520

Yamazaki, M. and M. Kobayashi 1969 Purification of the proteinic brain hormone of the silkworm, Bombyx mori. J. Insect Physiol., 15: 1981-1990 